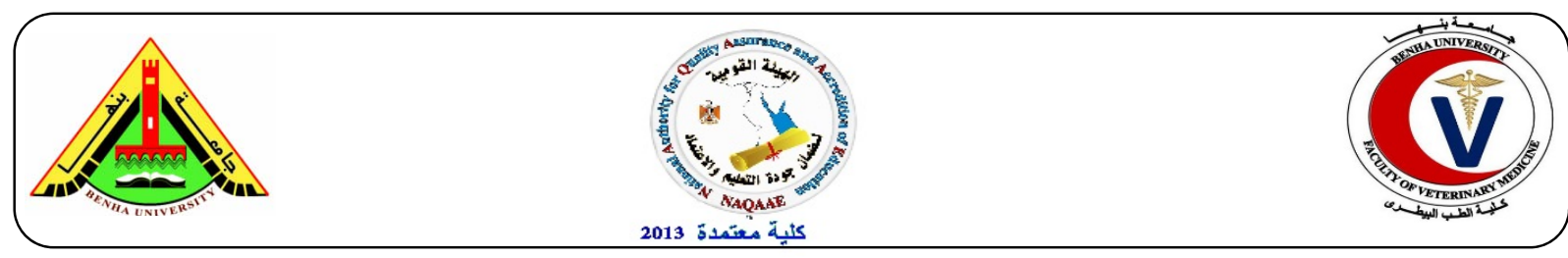

\title{
Antioxidant effect of selenium and its Nano form on oxidative stress induced by iron overload
}

\author{
Fararh, K.M. ${ }^{a}$ Farid, A.S. ${ }^{\text {a }}$, Abdalla, O.A. ${ }^{\mathrm{b}}$, Samah A. Algharib ${ }^{\mathrm{a}}$ \\ ${ }^{a}$ Clinical pathology dept., Faculty of Veterinary Medicine, Benha University. ${ }^{b}$ Clinical pathology dept., Faculty of \\ Veterinary Medicine, Suez Canal University.
}

\begin{abstract}
A B S T R A C T
The aim of this study was to demonstrate the antioxidant effect of selenium in its ordinary and Nano form on oxidative stress induced by iron overload in male rat. This study was carried out on 90 rat, weighted 180-200 gm. Rats were classified into six groups Group 1: control group. Group 2: Nano selenium-treated group. Group 3: selenium treated group. Group 4: iron overload treated group. Group 5: iron overload + Nano selenium - treatment. Group 6: iron overload + selenium-treatment. Blood and liver tissue samples were collected from all groups after 1, 3 and 6 weeks from the onset of the experiment. Serum used for measurement of total iron. Liver tissue was processed for measurement of molonadialdhyde (MDA), total antioxidant capacity (TAC), glutathione peroxidase (GSH-PX), super oxide dismutase (SOD), glutathione reduced (GSH) and Catalase. The obtained results revealed that, Nano-selenium + iron and selenium + iron-treated groups lead to decrease the concentration of MDA, total iron and significant decrease in GSH-PX-1 mRNA expression and increase the concentration of TAC, catalase, GSH and SOD when compared with iron overload treated group. From the result, it can be concluded that selenium in its ordinary and Nano forms have antioxidant and hepatoprotective effect in experimentally-induced iron overload in male Wister rats. Nano form has superior effects than ordinary form of selenium.
\end{abstract}

Keywords: Iron overload, Oxidative stress, Nano-selenium, Selenium, Antioxidants.

(http://www.bvmj.bu.edu.eg)

(BVMJ-31(1): 96-102, 2016)

\section{INTRODUCTION}

Iron is the most abundant transition metal in the body; it is the essential element for the utilization of oxygen, part of numerous oxidases and oxygenases (Galleano et al., 2004). It is an essential micronutrient for all living organisms and mainly present in protein-bound forms such as heme and non-heme proteins, playing a major role in electron transfer and deoxyribose nucleic acid (DNA) synthesis (Abbaspour et al., 2014). Although iron overload (IOL) is a less frequent condition, the high contents of tissue iron were associated with several pathological conditions, including liver and heart diseases (Rasmussen et al., 2001), neurodegenerative disorders (Berg et al., 2001), cancer (Parkkila et al., 2001), glucose intolerance (Jiang et al., 2004), immune system abnormalities (Li et al., 2000), Parkinson's disease, Alzheimer's disease and human immunodeficiency virus encephalopathy (Rouault, 2001). Iron participates in the Fenton reaction, the most basic reaction of oxidative stress and reactive oxygen species (ROS), which is frequently used to induce in vitro oxidative damage to macromolecules, including lipid peroxidation (LPO) (Gitto et al., 2001). It is also promoting oxidative stress in the liver of overloaded animal and human, which may trigger the expression of redox-sensitive genes (Cornejo et al., 2005). Liver is the main storage organ for iron, therefore; in IOL, free radical formation and generation of LPO products may result in progressive tissue injury and eventually cirrhosis or hepatocellular carcinoma (HCC) (Siah et al., 2005). Selenium, as one of the essential trace elements for the health of mammalian animals, has key functions in the balancing of the redox system, proper functions of the immune system, and anticarcinogenetic effects (El-Bayoumy, 2001). Importantly, Nano selenium can serve as antioxidant with reduced risk of selenium toxicity and as a potential chemopreventive agent (Wang et al., 2007). Therefore, the present study was designed to investigate the antioxidant effects of Nano selenium and selenium in iron overloadinduced oxidative stress.

\section{MATERIALS AND METHODS}




\subsection{Experimental animals:}

Ninety white male wistar rats weighing 180 $200 \mathrm{~g}$ were used in the experimental investigation of this study. Rats were obtained from United Co. for Chemical and medical preparation, Cairo, Egypt. Rats were housed in separated metal cages and kept at constant environmental and nutritional conditions throughout the period of the experiment. The animals provided with a constant supply of standard pellet diet and fresh, clean drinking water ad libitum.

\subsection{Drug and antioxidants:}

The drug and antioxidant compounds used in the present study were: Haemojet ${ }^{(R)}$ : Haemojet ampoules were produced by Amriya Pharm. Ind. for European Egyptian Pharma. Ind., Alexandria, Egypt. Each ampoule contains elemental iron (100 $\mathrm{mg}$ ) as ferric hydroxide polymaltose complex. Nano selenium: Selenium nanoparticles (3-20 nm particle size) sterilized solution dispersed in phosphate-buffered saline (PBS) and ready for use Abd-Allah and Hashem, (2015). Sodium selenite: Sodium selenite was obtained from (SigmaAldrich, Egypt). It was dissolved in phosphate buffer solution.

\subsection{Experimental design:}

Rats were randomly divided into six equal groups: each group contain 15 rats as follows: Group I (control group): received phosphate buffer saline only and served as control for all other groups. Group II (Nano selenium treated group): injected by $0.5 \mathrm{mg} / \mathrm{kg}$ body weight Nano selenium dispersed in $0.5 \mathrm{~mL}$ PBS IP three times per week for six weeks. Group III (selenium treated group): injected by $0.5 \mathrm{mg} / \mathrm{kg}$ body weight sodium selenite dispersed in $0.5 \mathrm{~mL}$ PBS IP three times per week for six weeks. Group IV (iron overload): injected by eight doses of ferric hydroxide polymaltose complex (12.5 mg/100 g body wt.) IP evenly distributed over 6 weeks. Group V (iron overload + Nano selenium-treated group): were given by eight doses of ferric hydroxide polymaltose complex $(12.5 \mathrm{mg} / 100 \mathrm{~g}$ body wt.) IP evenly distributed over 6 weeks and $0.5 \mathrm{mg} / \mathrm{kg}$ body weight Nano selenium dispersed in $0.5 \mathrm{~mL}$ PBS IP three times per week for 6 weeks at the same period of iron injection. Group VI (iron overload + selenium-treated group): were given by eight doses of ferric hydroxide polymaltose complex (12.5 $\mathrm{mg} / 100 \mathrm{~g}$ body wt.) IP evenly distributed over 6 weeks and $0.5 \mathrm{mg} / \mathrm{kg}$ body weight sodium selenite dispersed in $0.5 \mathrm{~mL}$ PBS IP three times per week for 6 weeks at the same period of iron injection.

\subsection{Sampling:}

Blood samples and liver tissue specimens were collected from all groups after 1, 3 and 6 weeks from the onset of the experiment.

\subsection{Biochemical analysis:}

Total serum iron was determined according to the methods described by Fairbanks and Klee, (1987). Moreover, liver MDA, GSH-px, SOD, GSH, TAC and catalase were determined according to the methods described by Kei, (1978); Paglia and Valentine, (1967); Nishikimi et al., (1972); Beutler et al., (1963); Koracevic et al., (2001) and Aebi, (1984) respectively.

\subsection{Statistical analysis:}

Statistical analysis was performed using the statistical package for social science (SPSS) for Windows (Version 16.0; SPSS Inc., Chicago, Ill.). One-way ANOVA test was used to determine significant differences among experimental groups with Duncan as a post hoc. Results are expressed as the mean \pm standard error of mean (SEM). A Pvalue of less than 0.05 was considered significant (SPSS, 2006).

\section{RESULTS}

\subsection{Effect of iron overload and/or treatment with Nano selenium and selenium on Antioxidant parameters and total serum iron:}

The results presented in Tables (1 and 2) revealed that, iron overload resulted in significant increases in serum iron, MDA and GSH-PX. Meanwhile, IOL decreased liver GSH, TAC, SOD and catalase levels when compared with the control rats. Nano selenium + iron and selenium +iron administration lead to decreased in serum iron, MDA and GSH-PX. Moreover, it significantly increased liver GSH level, TAC, SOD and Catalase

\subsection{Effect of iron overload and/or treatment with Nano selenium and selenium on GSH-PX mRNA expression:}

The results presented in Tables (3) revealed that, the hepatic expression of GSH-PX-1 was significantly increased (up-regulated) in iron overload-treated group compared with control group, while Nano selenium-treated and seleniumtreated groups showed non-significant decreases when compared with control group. Nano selenium +iron-treated group showed a significant decrease in expression of GSH-PX-1 when compared with iron overload-treated group. Selenium + irontreated group showed significant decrease in expression of GSH-PX-1 when compared with iron overload-treated group. 
Fararh et al. (2016). BVMJ-31(1): 96-102

Table (1): Anti-oxidant parameters and total serum iron after one week of intraperitoneal injection of iron and/or treatment with Nano selenium and selenium

\begin{tabular}{|c|c|c|c|c|c|c|c|}
\hline Groups & $\begin{array}{c}\text { MDA in } \\
\text { tissue } \\
\text { nmol/g. tissue }\end{array}$ & $\begin{array}{l}\text { GSH-PX } \\
\text { in Tissue } \\
\text { U/gT }\end{array}$ & $\begin{array}{c}\text { TAC } \\
\mathrm{mM} / \mathrm{g} . \text { tissue }\end{array}$ & $\begin{array}{c}\text { GSH } \\
\text { U/g. tissue }\end{array}$ & $\begin{array}{c}\text { SOD } \\
\text { U/g. tissue }\end{array}$ & $\begin{array}{c}\text { Catalase } \\
\text { U/L }\end{array}$ & $\begin{array}{l}\text { Total serum iron } \\
\qquad(\mu \mathrm{g} / \mathrm{dl})\end{array}$ \\
\hline Control & $421.11 \pm 50.66^{\mathrm{b}, \mathrm{c}}$ & $6011.09 \pm 191.00^{\mathrm{a}}$ & $217.65 \pm 1.91^{b}$ & $69.43 \pm 1.85^{\mathrm{b}}$ & $318.95 \pm 21.29^{\mathrm{b}, \mathrm{c}}$ & $497.55 \pm 19.98^{\mathrm{a}, \mathrm{b}}$ & $249.26 \pm 14.43^{c}$ \\
\hline Nano selenium & $182.10 \pm 17.77^{\mathrm{a}}$ & $6843.69 \pm 92.56^{\mathrm{b}}$ & $272.93 \pm 2.40^{c}$ & $81.27 \pm 2.33^{\mathrm{c}}$ & $570.79 \pm 39.01^{\mathrm{e}}$ & $715.32 \pm 21.40^{\mathrm{c}}$ & $132.96 \pm 4.81^{\mathrm{a}}$ \\
\hline Selenium & $344.06 \pm 50.49^{b}$ & $6291.23 \pm 222.87^{\mathrm{a}, \mathrm{b}}$ & $264.80 \pm 4.52^{\mathrm{c}}$ & $72.85 \pm 1.15^{\mathrm{b}}$ & $399.87 \pm 8.13^{\mathrm{d}}$ & $592.74 \pm 21.71^{\mathrm{b}}$ & $206.30 \pm 8.40^{\mathrm{b}}$ \\
\hline Iron overload & $549.19 \pm 59.06^{\mathrm{c}}$ & $6431.29 \pm 339.38^{\mathrm{a}, \mathrm{b}}$ & $205.26 \pm 1.32^{\mathrm{a}}$ & $59.51 \pm 2.27^{\mathrm{a}}$ & $142.10 \pm 20.68^{\mathrm{a}}$ & $416.13 \pm 21.39^{\mathrm{a}}$ & $507.04 \pm 23.03^{\mathrm{e}}$ \\
\hline Nano selenium + Iron & $331.45 \pm 44.95^{\mathrm{b}}$ & $6777.56 \pm 185.43^{\mathrm{b}}$ & $217.25 \pm 3.05^{\mathrm{b}}$ & $74.98 \pm 4.34^{\mathrm{b}, \mathrm{c}}$ & $360.00 \pm 21.94^{\mathrm{c}, \mathrm{d}}$ & $571.77 \pm 57.89^{b}$ & $266.67 \pm 11.77^{c}$ \\
\hline Selenium + Iron & $439.68 \pm 64.30^{\mathrm{b}, \mathrm{c}}$ & $6442.96 \pm 111.99^{\mathrm{a}, \mathrm{b}}$ & $208.99 \pm 2.57^{\mathrm{a}}$ & $69.97 \pm 0.94^{\mathrm{b}}$ & $261.71 \pm 5.43^{b}$ & $575.81 \pm 34.11^{\mathrm{b}}$ & $348.15 \pm 9.57^{d}$ \\
\hline
\end{tabular}

Results are expressed as mean \pm S.E.M. Different superscripts (a, b, c, d, e) in the same column indicate significant differences at $P<0.05$.

Table (2): Anti-oxidant parameters and total serum iron after six weeks of intraperitoneal injection of iron and/or treatment with nanoselenium and selenium:

\begin{tabular}{|c|c|c|c|c|c|c|c|}
\hline Groups & $\begin{array}{l}\text { MDA in tissue } \\
\text { nmol/g. tissue }\end{array}$ & $\begin{array}{c}\text { GSH-PX in Tissue } \\
\text { U/gT }\end{array}$ & $\begin{array}{c}\text { TAC } \\
\mathrm{mM} / \mathrm{g} \text {. tissue }\end{array}$ & $\begin{array}{c}\text { GSH } \\
\text { U/g. tissue }\end{array}$ & $\begin{array}{c}\text { SOD } \\
\text { U/g. tissue }\end{array}$ & $\begin{array}{c}\text { Catalase } \\
\text { U/L }\end{array}$ & $\begin{array}{c}\text { Total serum iron } \\
(\mu \mathrm{g} / \mathrm{dl})\end{array}$ \\
\hline Control & $240.84 \pm 10.17^{\mathrm{a}, \mathrm{b}}$ & $6291.22 \pm 121.89^{a}$ & $211.04 \pm 1.60^{\mathrm{a}}$ & $65.06 \pm 1.25^{\mathrm{b}}$ & $322.80 \pm 5.00^{\mathrm{c}}$ & $512.68 \pm 25.65^{\mathrm{b}}$ & $321.11 \pm 26.43^{\mathrm{c}}$ \\
\hline Nano selenium & $202.75 \pm 7.46^{\mathrm{a}}$ & $6614.15 \pm 137.29^{\mathrm{a}}$ & $225.49 \pm 2.81^{\mathrm{c}}$ & $95.10 \pm 4.16^{\mathrm{d}}$ & $388.57 \pm 20.05^{\mathrm{d}}$ & $845.07 \pm 29.62^{\mathrm{d}}$ & $139.95 \pm 12.68^{a}$ \\
\hline Selenium & $251.31 \pm 18.88^{\mathrm{a}, \mathrm{b}}$ & $6339.02 \pm 187.42^{\mathrm{a}}$ & & & $336.86 \pm 11.01^{\mathrm{c}}$ & $702.66 \pm 33.78^{c}$ & $224.38 \pm 10.60^{b}$ \\
\hline Iron overload & $511.18 \pm 40.26^{\mathrm{c}}$ & $7789.69 \pm 376.06^{\mathrm{b}}$ & $206.17 \pm 1.68^{\mathrm{a}}$ & $55.82 \pm 1.52^{\mathrm{a}}$ & $48.00 \pm 12.55^{\mathrm{a}}$ & $417.17 \pm 10.27^{\mathrm{a}}$ & $810.85 \pm 27.37^{\mathrm{f}}$ \\
\hline Nano selenium + Iron & $312.85 \pm 47.90^{\mathrm{b}}$ & $8206.55 \pm 210.18^{b}$ & $218.27 \pm 1.64^{\mathrm{b}}$ & $94.04 \pm 2.30^{\mathrm{d}}$ & $329.43 \pm 14.18^{\mathrm{c}}$ & $680.75 \pm 42.34^{\mathrm{c}}$ & $573.81 \pm 25.03^{\mathrm{d}}$ \\
\hline Selenium + Iron & $470.01 \pm 41.36^{\mathrm{c}}$ & $7826.74 \pm 337.60^{b}$ & $211.93 \pm 2.06^{\mathrm{a}}$ & $76.26 \pm 1.92^{\mathrm{c}}$ & $262.00 \pm 5.63^{\mathrm{b}}$ & $617.68 \pm 30.85^{\mathrm{c}}$ & $674.69 \pm 11.98^{\mathrm{e}}$ \\
\hline
\end{tabular}

Results are expressed as mean \pm S.E.M. Different superscripts (a, b, c, d, e, f) in the same column indicate significant differences at $P<0.05$. 
Table (3): The effect of iron overload and/or treatment with Nano selenium and selenium on expression of glutathione peroxidase (GSH-PX-1) in the male wister rat.

\begin{tabular}{lc}
\hline Groups & $($ GSH-PX)-1 \\
\hline Control & $1.00 \pm 0.04^{\mathrm{a}}$ \\
Nanoselenium & $0.69 \pm 0.05^{\mathrm{a}}$ \\
Selenium & $0.55 \pm 0.07^{\mathrm{a}}$ \\
Iron & $13.28 \pm 4.95^{\mathrm{c}}$ \\
Nanoselenium+Iron & $7.07 \pm 1.63^{\mathrm{b}}$ \\
Selenium+Iron & $1.93 \pm 0.09^{\mathrm{a}, \mathrm{b}}$ \\
\hline
\end{tabular}

Results are expressed as mean \pm S.E.M. Different letters $(\mathrm{a}, \mathrm{b}, \mathrm{c})$ indicate significant difference at $P<0.05$.

\section{DISCUSSION}

Recent years have witnessed unprecedented growth of research and applications in the area of nanoscience and nanotechnology, leading to the development of nanomaterials with enormous potential. They are being actively introduced as therapeutic in biomedicine (Magaye et al., 2012). An important goal for experimental approaches is to address the possible protective effect of nanoparticles as antioxidants for curing of damage in antioxidant deficiency status (De Jong and Borm, 2008).

Selenium is important for the control of oxidative stress and therefore the redox state of the cell. In particular, the level of antioxidant enzymes is a good indicator for the impacts of oxidants like iron overload (Segalés et al., 2005). In the case of oxidative stress, the MDA level was regarded as a good indicator for the level of lipid peroxidation (Shi et al., 2004). Our results revealed that iron overload induced significant increases in MDA levels in tissue when compared with the control. These findings are plausible in the context that I/P iron is a well-known inducer for lipid peroxidation in liver (Reddy and Lokesh, 1996; Khan et al., 2002). These results are in agreement with that of Arjumand et al., (2011); Jagetia and Reddy, (2011). Meanwhile, treating rats with selenium or Nano selenium significantly decreased the levels of MDA at hepatic tissue when compared with control groups. Additionally, treating rats with Nano selenium in the presence of iron caused significant decreases in the levels of hepatic and serum MDA when compared with groups received iron only.

Antioxidant enzymes are considered to be the first line of cellular defense against oxidative damage. The obtained results revealed that iron overload lead to significant decreases in catalase after 3 and 6 weeks when compared with control. Similarly, there were significant decreases in SOD and GSH after 1, 3 and 6 weeks and significant decrease in TAC after 1 and 3 weeks when compared with control. These results may be due to oxidative stress response in the liver by iron overload that characterized by the increase in protein carbonylation and the reduction in GSH as well as in GSH/GSSG ratio that observed after iron administration (Cornejo et al., 2005; Pardo-Andreu et al., 2008). These results are in agreement with that of Jagetia and Reddy, (2011) who found that iron administration into mouse liver mitochondrial fraction caused a time dependent depletion in GSH by $\sim 2$-fold lower than control at 30 minutes' posttreatment. Furthermore, IOL induced by diets supplemented with $2.5 \%$ carbonyl iron, resulted in a significant decrease of CAT activity in rat liver (Galleano and Puntarulo, 1997). Also, iron-dextran injection decreased the hepatic CAT activity (Zhao et al., 2005). Moreover, the presence of iron caused inhibition in the CAT activity which was reduced to less than half of the control value, and induced a significant decline in the SOD activity by $3.25-$ folds, when compared to the untreated control (Jagetia and Reddy, 2011).

Knowing that the liver is the primary organ responsible for the biosynthesis and exportation of the water soluble antioxidants (Dringen, 2000), it will be expected to induce enhanced hepatic free radical generation by iron that caused derangement of some antioxidant mechanisms of the liver cell, as GSH depletion, decreased SOD and CAT activities concomitantly with a substantial LPO response (Galleano and Puntarulo, 1992), in which ROS generated during normal cellular processes are immediately detoxified by endogenous antioxidants like GSH, CAT, glutathione reductase (GR), GPx, GST etc., but excessive ROS accumulation causes an antioxidant status imbalance, leading to LPO and GSH depletion (Kim et al., 2006).

Selenium treated groups showed significant increases in TAC, GSH and catalase after 6 weeks when compared with their corresponding control. Selenium +iron-treated groups showed significant increases in GSH, SOD and catalase after 6 weeks when compared with iron overload treated group. These results may be due to the important incorporation of selenium in the active site of many antioxidant enzymes in mammalian cell; like thioredoxin reductase, glutathione peroxidase and glutathione reductase (Flora et al., 2002), since both Nano selenium and selenium significantly increase the GSH concentration, SOD, TAC and catalase activities and significantly decrease MDA 
concentration when compared to control group (Shi et al., 2011; Abd-Allah and Hashem, 2015).

In regard to selenoprotein enzymes, we found that selenium in its nano form increased the levels of hepatic GSH-PX. These results are reasonable in the perspective that selenium is an important component of GSH-PX located in the active center of the enzyme. Therefore, the action of GSH-PX depends on the content of selenium (Xu et al., 2013). Interestingly, we found that both forms of selenium used in this study caused, although, nonsignificant, but unexpected down regulation in GSH-PX mRNA expression in the hepatic tissues in the absence of iron overload. This down regulation of hepatic GSH-PX suggesting that selenium overexposure had an adverse effect on GSH-PX expressions. The decrease of GSH-PX expressions may be the result of the breakdown of regulatory control and associated loss of protein synthesis that occurs during the process of cell damage induced by excess selenium (Rana et al., 1994). Tallandini et al., (1996) also reported that GSH-PX remained at normal values in fish injected with 0.1 or $0.2 \mathrm{ppm} \mathrm{Se}$, whereas it fell significantly when injected with excess selenium. However, this mechanistic regulation is reversed in the presence of iron insult which needs activated antioxidant enzymes to compete oxidative stress and associated inflammatory status (Mathy-Hartert et al., 2008). In the present study, mRNA levels of iron overloaded group tended to parallel the changes in selenoenzyme activities in liver tissue due to increased translation, transcription or stabilization of the mRNA (Bermano et al., 1995).

Concerning to iron parameters, our results revealed that iron overload lead to significant increases in serum total iron when compared with their corresponding control. These results are a direct consequence of iron over load resulted from continues I/P administration of iron. In such cases of iron overload, the natural storage and transport proteins such as ferritin and transferrin become saturated and overwhelmed, and then the iron spills over into other tissues and organs, and oxidative stress arises because of the catalytic activity of the metal ion on producing high reactive oxygen radicals, and finally leads to tissue injury (Zhao et al., 2005). Our results agreed with that of Nahdi et al., (2010); Aziza et al., (2014) who found iron overload resulted in significant increases in serum iron.

Nano selenium-treated group showed significant decrease in serum total iron when compared with their corresponding control. Selenium-treated group showed that there were significant decreases in serum total iron when compared with their corresponding control. The results of this study showed that Nano selenium treatment for iron IOL rats caused significant decreases in iron compared with iron overload group. Also, selenium treatment for iron IOL rats induced significant decreases in iron. These results may be caused due to a possible role for dietary selenium ions in moderating iron metabolism (Christensen et al., 2000). Also, previous works have shown that supplementation with sodium selenite can decrease heart tissue concentrations of iron and oxidative stress in the mouse (Bartfay, 2003).

It worthy to mention that Nano form of selenium has superior actions than the ordinary in regard to MDA, TAC, catalase, SOD, GSH and iron.

\section{CONCLUSION}

From the results of the present study, we can conclude that selenium in its ordinary and Nano forms has antioxidant and hepatoprotective effect in experimentally-induced iron overload in male Wister rats. With Nano form has superior effects than ordinary form of selenium indicated by: Nano selenium-treated group showed significant decrease in MDA and total serum iron. Also, there were significant increase in GSH, TAC, SOD and catalase when compared with selenium treated group. Nano selenium + iron-treated group showed significant decrease in MDA and total serum iron. Also, there were significant increase in GSH, TAC, SOD and catalase when compared with selenium + iron-treated group.

\section{REFERENCES}

Abbaspour, N., Hurrell, R., Kelishadi, R. 2014. Review on iron and its importance for human health. J Res Med Sci 19, 164-174.

Abd-Allah, S., Hashem, K.S. 2015. Selenium nanoparticles increase the testicular antioxidant activity and spermatogenesis in male rats as compared to ordinary selenium. International Journal 3, 792-802.

Aebi, H. 1984. Catalase in vitro. Methods in enzymology 105, 121-126.

Arjumand, W., Seth, A., Sultana, S. 2011. Rutin attenuates cisplatin induced renal inflammation and apoptosis by reducing $\mathrm{NF} \kappa \mathrm{B}, \mathrm{TNF}-\alpha$ and caspase- 3 expression in wistar rats. Food and chemical toxicology 49, 2013-2021.

Aziza, S.A.H., Azab, M.E.S., El-Shall, S.K. 2014. Ameliorating role of rutin on oxidative stress induced by iron overload in hepatic tissue of 
rats. Pakistan Journal of Biological Sciences 17, 964.

Bartfay, W. 2003. Selenium status and the pathogenesis of iron overload cardiomyopathies: cause o consequence. Queen's Health Science 6, 40-46.

Berg, D., Gerlach, M., Youdim, M.B., Double, K.L., Zecca, L., Riederer, P., Becker, G. 2001. Brain iron pathways and their relevance to Parkinson's disease. $J$ Neurochem 79, 225-236.

Bermano, G., Nicol, F., Dyer, J., Sunde, R., Beckett, G., Arthur, J., Hesketh, J. 1995. Tissue-specific regulation of selenoenzyme gene expression during selenium deficiency in rats. Biochemical journal 311, 425-430.

Beutler, E., Duron, O., Kelly, B.M. 1963. Improved method for the determination of blood glutathione. The Journal of laboratory and clinical medicine 61, 882-888.

Christensen, M.J., Olsen, C.A., Hansen, D.V., Ballif, B.C. 2000. Selenium regulates expression in rat liver of genes for proteins involved in iron metabolism. Biol Trace Elem Res 74, 55-70.

Cornejo, P., Varela, P., Videla, L.A., Fernandez, V. 2005. Chronic iron overload enhances inducible nitric oxide synthase expression in rat liver. Nitric Oxide 13, 54-61.

De Jong, W.H., Borm, P.J. 2008. Drug delivery and nanoparticles: applications and hazards. International journal of nanomedicine 3, 133.

Dringen, R. 2000. Metabolism and functions of glutathione in brain. Progress in neurobiology 62, 649-671.

El-Bayoumy, K. 2001. The protective role of selenium on genetic damage and on cancer. Mutation Research/Fundamental and Molecular Mechanisms of Mutagenesis 475, 123-139.

Fairbanks, V., Klee, G. 1987. Biochemical aspect of haematology, 803-804. Fundamentals of Clinical Chemistry, NW Tietz (Ed), Saunders, Philadelphia.

Flora, S.J., Kannan, G.M., Pant, B.P., Jaiswal, D.K. 2002. Combined administration of oxalic acid, succimer and its analogue for the reversal of gallium arsenide-induced oxidative stress in rats. Archives of toxicology 76, 269-276.

Galleano, M., Puntarulo, S. 1992. Hepatic chemiluminescence and lipid peroxidation in mild iron overload. Toxicology 76, 27-38.

Galleano, M., Simontacchi, M., Puntarulo, S. 2004. Nitric oxide and iron: effect of iron overload on nitric oxide production in endotoxemia. Mol Aspects Med 25, 141-154.

Gitto, E., Tan, D.X., Reiter, R.J., Karbownik, M., Manchester, L.C., Cuzzocrea, S., Fulia, F., Barberi, I. 2001. Individual and synergistic antioxidative actions of melatonin: studies with vitamin $\mathrm{E}$, vitamin $\mathrm{C}$, glutathione and desferrioxamine (desferoxamine) in rat liver homogenates. J Pharm Pharmacol 53, 13931401.

Jagetia, G.C., Reddy, T.K. 2011. Alleviation of iron induced oxidative stress by the grape fruit flavanone naringin in vitro. Chemicobiological interactions 190, 121-128.

Jiang, R., Manson, J.E., Meigs, J.B., Ma, J., Rifai, N., Hu, F.B. 2004. Body iron stores in relation to risk of type 2 diabetes in apparently healthy women. JAMA 291, 711717.

Kei, S. 1978. Serum lipid peroxide in cerebrovascular disorders determined by a new colorimetric method. Clinica chimica acta 90, 37-43.

Khan, M.F., Wu, X., Tipnis, U.R., Ansari, G., Boor, P.J. 2002. Protein adducts of malondialdehyde and 4-hydroxynonenal in livers of iron loaded rats: quantitation and localization. Toxicology 173, 193-201.

Kim, Y.H., Kim, Y.W., Oh, Y.J., Back, N.I., Chung, S.A., Chung, H.G., Jeong, T.S., Choi, M.S., Lee, K.T. 2006. Protective effect of the ethanol extract of the roots of Brassica rapa on cisplatin-induced nephrotoxicity in LLC-PK1 cells and rats. Biological and Pharmaceutical Bulletin 29, 2436-2441.

Koracevic, D., Koracevic, G., Djordjevic, V., Andrejevic, S., Cosic, V. 2001. Method for the measurement of antioxidant activity in human fluids. Journal of clinical pathology 54, 356-361.

Li, J., Zhu, Y., Singal, D.P. 2000. HFE gene mutations in patients with rheumatoid arthritis. J Rheumatol 27, 2074-2077.

Magaye, R., Zhao, J., Bowman, L., Ding, M. 2012. Genotoxicity and carcinogenicity of cobalt-, nickel-and copper-based nanoparticles (Review). Experimental and therapeutic medicine 4, 551-561.

Mathy-Hartert, M., Hogge, L., Sanchez, C., DebyDupont, G., Crielaard, J.M., Henrotin, Y. 2008. Interleukin-1 $\beta$ and interleukin-6 disturb the antioxidant enzyme system in bovine chondrocytes: a possible explanation for oxidative stress generation. Osteoarthritis and Cartilage 16, 756-763.

Nahdi, A., Hammami, I., Kouidhi, W., Chargui, A., Ben Ammar, A., Hamdaoui, M.H., El May, 
A., El May, M. 2010. Protective effects of crude garlic by reducing iron-mediated oxidative stress, proliferation and autophagy in rats. $J$ Mol Histol 41, 233-245.

Nishikimi, M., Roa, N., Yogi, K. 1972. Measurement of superoxide dismutase. Biochem. Biophys. Res. Common 46, 849854.

Paglia, D.E., Valentine, W.N. 1967. Studies on the quantitative and qualitative characterization of erythrocyte glutathione peroxidase. The Journal of laboratory and clinical medicine 70, 158-169.

Pardo-Andreu, G.L., Barrios, M.F., Curti, C., Hernández, I., Merino, N., Lemus, Y., Martínez, I., Riano, A., Delgado, R. 2008. Protective effects of Mangifera indica L extract (Vimang), and its major component mangiferin, on iron-induced oxidative damage to rat serum and liver. Pharmacological Research 57, 79-86.

Parkkila, S., Niemela, O., Savolainen, E.R., Koistinen, P. 2001. HFE mutations do not account for transfusional iron overload in patients with acute myeloid leukemia. Transfusion 41, 828-831.

Rana, M.P., Ghosh, R., Chatterjee, M. 1994. Changes in tissue levels of glutathione, extent of lipid peroxidation, and activity of glutathione peroxidase in transplantable murine lymphoma. Oncology 51, 25-29.

Rasmussen, M.L., Folsom, A.R., Catellier, D.J., Tsai, M.Y., Garg, U., Eckfeldt, J.H. 2001. A prospective study of coronary heart disease and the hemochromatosis gene (HFE) C282Y mutation: the Atherosclerosis Risk in Communities (ARIC) study. Atherosclerosis 154, 739-746.

Reddy, A.C.P., Lokesh, B. 1996. Effect of curcumin and eugenol on iron-induced hepatic toxicity in rats. Toxicology 107, 3945.

Rouault, T.A. 2001. Iron on the brain. Nat Genet 28, 299-300.

Segalés, J., Allan, G.M., Domingo, M. 2005. Porcine circovirus diseases. Animal Health Research Reviews 6, 119-142.

Shi, H., Hudson, L.G., Liu, K.J. 2004. Oxidative stress and apoptosis in metal ion-induced carcinogenesis. Free Radical Biology and Medicine 37, 582-593.

Shi, L., Xun, W., Yue, W., Zhang, C., Ren, Y., Shi, L., Wang, Q., Yang, R., Lei, F. 2011. Effect of sodium selenite, Se-yeast and nanoelemental selenium on growth performance, Se concentration and antioxidant status in growing male goats. Small Ruminant Research 96, 49-52.

Siah, C.W., Trinder, D., Olynyk, J.K. 2005. Iron overload. Clin Chim Acta 358, 24-36.

SPSS. 2006: SPSS 15.0 Command Syntax Reference. Chicago, Illinois: SPSS Inc.

Tallandini, L., Cecchi, R., De Boni, S., Galassini, S., Ghermandi, G., Gialanella, G., Liu, N., Moro, R., Turchetto, M., Zhang, Y. 1996. Toxic levels of selenium in enzymes and selenium uptake in tissues of a marine fish. Biol Trace Elem Res 51, 97-106.

Wang, H., Zhang, J., Yu, H. 2007. Elemental selenium at nano size possesses lower toxicity without compromising the fundamental effect on selenoenzymes: comparison with selenomethionine in mice. Free Radical Biology and Medicine 42, 1524-1533.

Zhao, Y., Li, H., Gao, Z., Xu, H. 2005. Effects of dietary baicalin supplementation on iron overload-induced mouse liver oxidative injury. European journal of pharmacology 509, 195-200. 